\title{
VISUALIZATIONS
}

\section{Visualization of migration using spatial interpolation method in Hungary and Slovakia}

\section{Ladislav Novotný}

Pavol Jozef Šafárik University in Košice Faculty of Science

Institute of Geography,

Slovakia

E-mail: ladislav.novotny@upjs.sk

\section{Loránt Pregi}

Pavol Jozef Šafárik University in Košice

Faculty of Science

Institute of Geography,

Slovakia

E-mail: lorant.pregi@upjs.sk

Reducing the intensity of natural reproduction of population in the post-socialist central and eastern European countries (CEECs) led to stabilization of natural increase near the equilibrium or even at the negative values by the early 2000s (cf. Berde-Németh 2014, Mládek 2008, Vörös-Torma 2016). At the same time, rise of intensity, effectiveness and substantial changes in spatial patterns of migration (Bezák 2006, Mykhnenko-Turok 2008, Novotný 2016) spurred attention to the research of migration as a phenomenon gaining important role in spatial redistribution of population (Bezák 2006, Kulcsár-Obádovics 2016).

To visualize migration, traditionally choropleth or diagram maps (Pravda 2007) are used. Choropleth maps provide important information for displayed administrative or statistical units, but the various size of these spatial units and the shapes of their boundaries can distort visual perception of migration patterns on large scale maps. This is not the case when diagram maps are used but they fail to display population as a spatially continuous phenomenon. However, the population has a certain impact on every point in the area regardless if people directly reside on it or not, what makes perception of population as a continuous phenomenon relevant.

The aim of this study is to display internal migration as a spatially continuous phenomenon, and so to visualize the impact of migration balance of individual municipalities throughout the whole area of Hungary and Slovakia, which are concerned as a case study. For that purpose, the interpolation cartographic method is employed. The added value of the study lies in the introduction of spatial interpolation method into the research and visualization of migration.

The statistical analysis is based on annual data on migration at the level of individual municipalities (LAU2) in Hungary and Slovakia, provided by the national statistical offices for the period 1996-2017 (KSH 2018a, KSH 2018b, ŠÚSR 1996-2017, ŠÚSR 2017). Although international migration is not negligible regarding changes of spatial distribution of population in CEECs, it is omitted in this paper due to methodological incompatibility of registration of internal and international migration by competent authorities (Novotný 2016). Total change in the number of inhabitants caused by migration in a given area is indicated by net migra-

Regional Statistics, Vol. 8. No. 2. 2018: 184-188; DOI: 10.15196/RS080206 
tion while net migration rate indicates relative impact of net migration referring to the mid-year population of a given LAU2.

The visualization employs the inverse distance weighting (IDW) method which applies the basic geostatistical principle: phenomena closer to one another are more alike than those farther apart. This leads to the assumption that each point in space with the known value of visualized phenomenon has a local influence which diminishes with distance. In consequence the values for each point on the map are estimated examining all points with known values within given radius (GIS resources 2018).

This method is often used for visualizations of physical-geographic phenomena but has been very rarely employed in population analyses. Mainly because such analyses use data that are available for every chosen statistical unit, and there is no need to estimate them by interpolation. Even in this visualization, the data are available for each municipality. We assume that each point in space is in some relation with the population living in proximity and so, a migration increase can indicate rising intensity of human influence on the area and vice versa. However, statistical data are not available for each point in space but only as values aggregated for statistical units, usually municipalities. Thus, we transformed the principle of IDW into the assumption that the impact of a local population decreases with distance. The values of net migration and net migration rate are considered as values for the central point of each municipality area.

Whether using net migration or annual average net migration rate the visualizations have some common features. They show that the areas in the west tend to reach migration gains while migration losses are more likely in the eastern parts of both countries. The decentralization of population from major cities to their hinterlands is also visible.

When using net migration, migration losses in cities and larger towns are more visible. Achromatic diagrams are depicted in the map to visualize this trend clearly. Budapest, as the largest city recorded the largest loss, followed by Košice - the second largest city in Slovakia and the third in the whole area. Bratislava, the second largest city and the capital of Slovakia recorded only an insignificant loss. This approach shows total changes in spatial redistribution of population by migration but does not necessarily show relative impact of migration to the size of population in given areas. The same value of net migration can have insignificant impact on the population in a large city but a fundamental one in a small rural community. Therefore, the annual average net migration rate was visualized in another map.

Regional Statistics, Vol. 8. No. 2. 2018: 184-188; DOI: 10.15196/RS080206 
Visualization of migration using inverse distance weighted (IDW) interpolation method in Hungary and Slovakia, 1996-2017
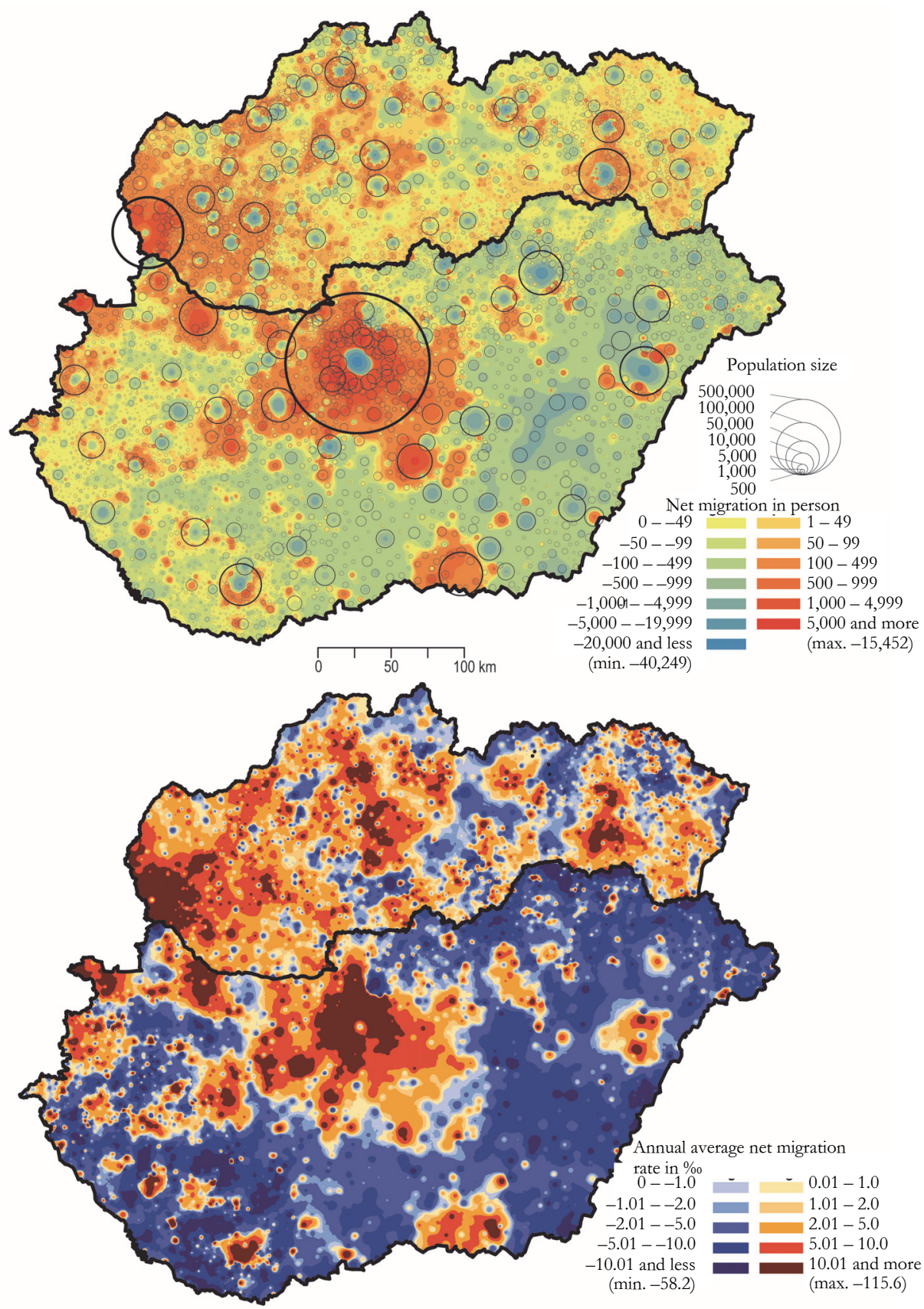

Regional Statistics, Vol. 8. No. 2. 2018: 184-188; DOI: 10.15196/RS080206 
It confirms that even large migration losses in the majority of the cities had only modest impact on their population size. However, these cities seem to act as sources of migrants contributing to the rapid population growth of adjacent areas. This trend has the largest extent in the metropolitan areas of Budapest and Bratislava but is seen even around other cities and larger towns. The maps also show migration attractiveness of the areas close to Austria with the exception of a smaller area in Hungary, south of Bratislava. In fact, this is the area where the decentralization of population from Bratislava was recorded (Novotný 2016), but the international migration is not considered in this paper. Generally, the results show that migration contributed to the increase of human impact to the landscape mainly in metropoli$\tan$ regions and in the proximity of other cities and larger towns, and to its decrease in peripheral regions. The spatial differentiation of the impact of migration is more significant in Hungary.

Software: ArcGIS 10.6.1

\section{Acknowledgement}

This work was supported by the Grant VEGA 1/0395/17 and the Grant VVGS-PF $2018 / 782$.

\section{REFERENCES}

BERDE, É.-NÉMETH, P. (2014): Az alacsony magyarországi termékenység új megközelítésben. Statisztikai Szemle, 92 (3), 253-275

BEZÁK, A. (2006): Vnútorné migrácie na Slovensku: súčasné trendy a priestorové vzorce. Geografický časopis, 58 (1), 15-44.

GIS RESOURCES (2018): Types of Interpolation Methods. Avalaible at: http://www.gisresources.com/types-of-interpolation-methods_2/

KulCsÁr, L.-OBÁDOVICS, Cs. (2016): Népességdinamika és társadalmi szerkezet. Területi Statisztika, 56 (4), 390-414. DOI: 10.15196/TS560403

MLÁDEK, J. (2008): Stabilizácia populačného vývoja Slovenska na úrovni stacionárnej populácie. Acta Geographica Universitatis Comenianae, 50, 63-78.

MykhenkO, V.-TuroK, I. (2008): East European cities - Patterns of growth and decline, 1960-2005. International Planning Studies, 13(4), 311-342. DOI: $10.1080 / 13563470802518958$

NovOtNÝ, L. (2016): Urban development and migration processes in the urban region of Bratislava from the postsocialist transformation until the global economic crisis. Urban geography, 37, 1009-1029. DOI: 10.1080/02723638.2016.1139413

PravdA, J. (2007): Mapy v atlase obyvatel'stva Slovenska. Kartografické listy, 15, 106-115.

VÖRÖS-TORMA, K. (2016): Magyarország településeinek kedvezőtlen népesedési folyamatai. Köztes-Európa, 8 (1-2), 5-15.

Regional Statistics, Vol. 8. No. 2. 2018: 184-188; DOI: 10.15196/RS080206 


\section{REFERENCES}

KSH (2018a): A lakónépesség száma, Budapest: Központi Statisztikai Hivatal.

KSH (2018b): Magyarország településeinek belföldi vándorlási adatai 1990-2017, Budapest: Központi Statisztikai Hivatal.

ŠÚSR (1996-2017): Bilancia pohybu obyvatel'stva Slovenskej republiky na úrovni obcí. Bratislava: Štatistický úrad Slovenskej republiky.

ŠÚSR (2017): Anonymizované mikrodáta o jednotlivých migráciách medzi obcami v rámci SR za obdobie 1996-2016. Bratislava: Štatistický úrad Slovenskej republiky.

Regional Statistics, Vol. 8. No. 2. 2018: 184-188; DOI: 10.15196/RS080206 